Theme D: Mathematics for all: why? what? when? In C. Winsløw (ed.), Nordic research in mathematics education. Rotterdam: Sense Publishers.

\title{
LIFELONG MATHEMATICS EDUCATION (1): NEEDS AND CONSTRAINTS
}

\author{
Tine Wedege and Paola Valero \\ Malmö University, Sweden; Aalborg University, Denmark
}

\section{MOTIVATION}

The idea of lifelong learning is now supposed to structure education in the Nordic countries. Formerly, the institutionalised framework of education (in the sense of formation) was only applied to children and young people. Today, the right and the obligation concerning education do not stop with childhood and youth but include adult life. In adult and continuing education there seems to be two parallel and combined processes going on: an institutionalizing process adding schools for adults to the schools for children and adolescents, and a de-institutionalizing process with a focus on adults' learning processes outside schools (Wedege, 2004). According to Rubenson (2001), "lifelong learning" was introduced by UNESCO in the late 1960s as a utopian-humanistic principle. Then it disappeared from the policy debate but reappeared in the late 1980s where the interest was based on an economistic worldview emphasising the importance of highly developed human capital and technology. From the late 1990s, it seems that a third generation of lifelong learning, an economisticsocial cohesion view, is taking over. This trend emphasises active citizenship and employability as two equally important aims for lifelong learning - at least on the rhetoric level. The first generation saw a strong role for civil society while the second generation privileged the market. In the third generation, the market still has a central role but the responsibilities of the individual and the state are also visible.

In this scenario, politicians, researchers and teachers might give different answers to the question "why mathematics for all?" However, during the political debate and the educational planning process of the new Danish adult education mathematics programme in 2000 to 2001, "active citizenship”, “employability” and "personal needs" were used as equivalent arguments (Johansen, 2006). Among these reasons we recognize the economy to be decisive at the political level: technological development at the labour market is the main reason for demanding mathematics education to all and, in this context, people's everyday competences do not count as mathematics (FitzSimons, 2002). Mathematics is to a large extent invisible in people's everyday life and they do not feel it relevant to study mathematics. One of the reasons is that people experience themselves as competent in their jobs without being aware of how mathematics plays a role in their activity (Wedege, 2000). Thus, mathematics education is experienced by the learners as a field of tension between felt needs concerning what one wants to learn - or has to learn - and various constraints from society and labour market (Wedege and Evans, 2006). 
Theme D: Mathematics for all: why? what? when? In C. Winsløw (ed.), Nordic research in mathematics education. Rotterdam: Sense Publishers.

\section{QUESTIONS FOR DISCUSSION}

From the perspective of lifelong learning, the term "mathematics" comes closer to definitions of the necessary mathematical competence in people's everyday life, and conceptions of "mathematical literacy" and "numeracy" are construed from different perspectives based on values and rationales of the stakeholders, as Jablonka (2003) has shown. She locates the following five perspectives: Mathematical literacy for developing human capital; for cultural identity; for social change; for environmental awareness; and for evaluating mathematics. Furthermore, in a study of mathematical literacy/numeracy two different lines of approach are possible and intertwined in the research: a subjective approach starting with people's subjective needs (see FitzSimons, 2002; Wedege, 2000), and an objective approach starting either with societal and labour market demands or with the academic discipline (transformed into "school mathematics"). However, if you want to understand the affective and social conditions for people's learning processes in mathematics then you have to take both dimensions into account (Valero, 2002; Wedege, 2000). Thus, we proposed the following two questions to be explored in the first topic group on lifelong mathematics education:

1. How is it possible to combine the subjective and the objective approaches in a study on mathematical literacy/numeracy?

2. How do we take into account the tension between people's needs and societal demands in a concept of mathematical literacy/numeracy?

Our point of departure was that any concept of mathematical literacy/numeracy, almost by definition, has to be construed on a basis of an idea of "mathematics for all".

\section{DEBATE}

In the session at NORMA08, we invited participants to explore these questions after a very short motivation for discussion.

The starting point of research and education might be the subjective perspective with a focus on the individual adult learner and her/his mathematics-containing competences and needs in mathematics. But we do not have to neglect the objective perspective on numeracy with requirements from society (democracy and labour market) and demands from school mathematics in the adult and further education system (see Wedege, 2008). As to mathematics in society, it is common among teachers and researchers in mathematics education to claim that mathematics is everywhere and thus important for all to learn and stating this without any scientific arguments. Even people like Alan Bishop (1999, p.1) write clichés like this: "Modern society is demanding much greater mathematical knowledge of its citizens than ever before”.

However, there has not been much research done to legitimate and to qualify this claim on the growing need for mathematics in society; a claim which is almost like a 
Theme D: Mathematics for all: why? what? when? In C. Winsløw (ed.), Nordic research in mathematics education. Rotterdam: Sense Publishers.

creed. Nevertheless, according to the international surveys, 25\% of the Danish adult population is defined as having inadequate basic skills by "international experts". We need a much grander scale of empirical research - into people's everyday lives combining the two perspectives: societal requirements and individual needs in order to respect and to give possibilities for adults to further develop their important but unrecognised mathematical skills and knowledge.

In the sentence quoted above, Bishop continues: "and the essential challenge for mathematics educators concerned with issues of democracy is how to provide an adequate mathematics education for the greatest number of citizens." The issues about needs and demands (individual/society) raised a discussion which revealed that we did not have the same answer to the question: What is an adequate mathematics education? What mathematics should be taught to all? Or to the fundamental question: What is mathematics? We also revealed that there are some dilemmas build into the third generation of "lifelong learning". During this debate Valero did this comment: If a sociologist listened to you he would say: "What a nice ideological dialogue you have here." Indeed, the justification of "Why mathematics for all" calls for value based answers. In her plenary lecture later at NORMA08, Artique stated: "Mathematics education is a field where science and values strongly inter-twin and we have to deal with it. (...) This is not only an obstacle, it is also a chance."

On the basis of the discussion in theme group "Lifelong mathematics education: needs and constraints" (1) it was possible to conclude:

- We, the researchers, have to declare our selves - what do we mean by mathematics.

- We need empirical research on the needs for mathematics of societies (in terms of mathematical-containing competences) and on the dialectical interplay with the needs for mathematics of the individuals.

For the participants also going to theme group "Lifelong mathematics education (2)" it was possible to draw on the discussion from this group in the debate of different constructions of "power" in relation to mathematics and mathematics education and their consequences for research and education.

\section{REFERENCES}

Bishop, A. (1999). Mathematics teaching and values education: an intersection in need of research. Zentralblatt für Didaktik der Mathematik, 31(1), 1-6.

FitzSimons, G. E. (2002). What counts as mathematics? Dordrecht: Kluwer Academic Publishers.

Jablonka, E. (2003). Mathematical Literacy. In A. J. Bishop et al. (Eds.), Second International Handbook of Mathematics Education (pp. 75-102). Dordrecht: Kluwer Academic Publishers. 
Theme D: Mathematics for all: why? what? when? In C. Winsløw (ed.), Nordic research in mathematics education. Rotterdam: Sense Publishers.

Johansen, L. Ø. (2006). Hvorfor skal voksne tilbydes undervisning i matematik? [Why offer mathematics education to adults?] (Doctoral thesis) Aalborg: DCN, Aalborg University.

Rubenson, K. (2001). Lifelong Learning for All: Challenges and Limitations of Public Policy. In The Swedish Ministry of Education and Science European Conference: Adult lifelong learning in a Europe of knowledge. Eskildstuna March 23-25. 2001.

Valero, P. (2002). The myth of the active learner: From cognitive to socio-political interpretations of students in mathematics classrooms. In P. Valero \& O. Skovsmose (eds.), Proceedings of the Third International Conference on Mathematics Education and Society (pp. 489-500). Copenhagen: Center for research in learning mathematics.

Wedege, T. (2000). Technology, Competences and Mathematics. In D. Coben; G. FitzSimons \& J. O’Donoghue (Eds.), Perspectives on adults learning mathematics: Research and practice (pp. 192-209). Dordrecht: Kluwer Academic Publishers.

Wedege, T. (2004). Lifelong learning of mathematics, focus on adult education. In I. M. Stedøy (ed.), Mathematics education: The Nordic way. A pre ICME-10 production (pp.41-50). Trondheim: Norwegian Center for Mathematics Education.

Wedege, T. \& Evans, J. (2006). Adults' resistance to learn in school versus adults' competences in work: the case of mathematics. Adults Learning Mathematics: an International Journal 1(2), 28-43.

Wedege, T. (2008). Adults learning mathematics: research and education in Denmark. To be published in B. Sriraman et al. (eds.), The sourcebook on Nordic research in mathematics education. Charlotte, NC: Information Age Publishing. 